\title{
Knowledge Economy in a Globalised India: Who Gets What?
}

\author{
June Cahyaningtyas \\ Jurusan Hubungan Internasional \\ Universitas Pembangunan Nasional "Veteran" Yogyakarta
}

\begin{abstract}
At the beginning of the $21^{\text {st }}$ century, the world started to spot India as one of the global epicenter of Information Technology (IT) industry. Unlike any other industries, IT caters the idea of knowledge and market, two essential pillars in the knowledge economy. Also, unlike the old type of financial economy which tends to be excessive due to its weighting on growth development, the term knowledge economy brings the idea of human capital investment and greater opportunity for vertical mobilization, hence promises more social equity. However, despite a more positive outlook towards India, records on poverty, malnutrition, and other social issues in India seem unmoved. This paper attempts to highlight how IT industry has actually developed in India and how likely it will lead to.
\end{abstract}

Keywords: IT, knowledge economy, India

Di awal abad 21, dunia mulai melihat India sebagai salah satu pusat industri teknologi informasi (information technology/IT) di dunia. Tidak seperti industri lainnya, industri IT mempromosikan pembangunan ekonomi berbasis pengetahuan (knowledge) dan pasar (market), dua pilar penting dalam gagasan ekonomi pengetahuan (knowledge economy). Selain itu, tidak seperti konsep ekonomi finansial yang cenderung menjadi eksesif karena penekanannya pada pembangunan berbasis pertumbuhan ekonomi semata, konsep knowledge economy membawa gagasan mengenai pentingnya investasi sumber daya manusia, memberi kesempatan yang lebih besar untuk terjadinya mobilisasi vertikal, dan menjanjikan ekuitas sosial yang lebih tinggi pula. Di sisi lain, sekalipun terdapat pandangan yang lebih positif mengenai India di masa depan dari berkembangnya industri IT di India, catatan mengenai kemiskinan, malnutrisi, dan isu sosial lainnya masih saja bertahan. Artikel ini mengupas sejauh mana pengaruh industri IT terhadap masyarakat di India di masa kini dan yang akan datang.

Kata-Kata Kunci: IT, knowledge economy, India 
The famous depiction of India is divided between rampant poverty, malnutrition, uneducated children, slum areas, yet warm sociability (Lapierre 1985) on the one hand and prosperity, modern, high skill human resources, and globalised economy (Das 2010) on the other hand. Time-wise, the latter depiction may have altered the former one, as one may argue, but for others these two depictions may not be relevant at all for comparison, since each belongs to particular time and space. Interestingly, on 26 August 2008, IBNLive published coverage on the increasing number of poor people in India, but a day later The Business Standard published an article which stated explicitly that the number of poor in India has been steadily decreasing since 1985 . What makes this case interesting is that the two media took its claim from the same World Bank report on the state of poverty in India. It is arguable that India remains to be diverted into the two opposing poles of attribution, but the question is, how much have this gap been reduced or even enhanced by the drive of globalization?

Attempting to delve into this matter, the paper would like to discuss the issue of knowledge economy, specifically Information Technology (IT) by which India is now being globally recognized. IT that used to be related to skilled professional among Indian migrant workers becomes one of the most studied aspects in knowledge economy of India. Some research focus on the relations between the Indian overseas and the creation of Indian global production network, specifically, the development of IT industry (Radakrishnan 2011; Das 2010; Dossani 2005). Other research focus on gender-specific analysis, that is how IT has influenced, for better or worse, the life of women in India (Clark and Sekher, 2007; Arun, Heeks, and Morgan, 2004) Instead of concentrating on the global production networks of Indians in IT sector, this paper focuses on the extent to which IT has transformed the landscape of Indian society. Rather than probing on gender criteria alone, the course of the analysis will be seen from the impact of IT industry to all Indians. To be specific, the paper questions whether knowledge economy brings equal opportunities for all, or whether it has sharpened the existing gaps and disparities?

\section{Knowledge Economy and Social Mobility of Indians}

The term knowledge economy marks the synthesis between knowledge (science and technology) and economy (market), or what Kellner described as "the increasingly important role of technology and the enduring primacy of capitalist relations of production" (Kellner, 2002, online version, no page number can be attributed). Globalization caters the spread of knowledge and IT to all places in the world. On places where IT has been being introduced, the likelihood of utilizing 
knowledge and IT for coping with problems in society is higher and the creation of knowledge economy is a lot more possible. On paper, the creation of knowledge economy is seen positively because it secures intellectual capital which is necessary for economic, social, and political advancement. In aggregate, knowledge economy sets forth national development through the opening up of social mobility. But this premise may not always be the case for countries where gaps and inequalities are prevalent, such as India. Globalist outlook tends to view the importance of knowledge economy in India which brings about structural changes in Indian society, through the improvement of education, the development of research and science, and the achievement in technology, of which market becomes the key driver. Imbued with axes of inequalities, which are generated by multilayered diversity and cultural heterogeneity, India becomes a special case to look at. Where gaps and inequalities exist, increase competition for 'knowledge' jobs means a greater emphasis on the level of education acquired. In the course of time, as the landscape change from the blue-collar work to white-collar work orientation, increase competition will only be won by those who are educated and high skilled (Bell 1973, 21).

The birth of IT industry in India was initially set out by market opportunity. Until 1970s the government policy on IT development was hostile. Bound by the premise of economic protectionism, IT was severely underdeveloped due to limited access to foreign investment and banking credits (Dossani 2005, 14). This hostile policy environment has eventually led to labor exports, which during the 1970s-1990s inhibit the inflows of skilled labor in India due to the high capital flight on certain period of time but, eventually, in 2000 s created a returned skilled human resources (Dossani 2005, 16). In 1980s, government started to project IT as an important sector for economic growth and, from then on, a set of new regulation was promulgated to welcome investors. In 1990 and 2000, for instance, tariff was reduced to nearly zero and a number of regulations on "standardized foreign ownership, intellectual property protection, venture capital, stock market listing, and telecommunication policies to global best practice" went promoted (Dossani 2005, 24). No less important was a shift of policy in education in 2000 that enable foreign investment on higher education, including privately funding engineering colleges in the south and the west region. The later policy became one of the propellers for the growth of software industry in those regions (Arora and Badge 2007, 2). Many globalist view the development of IT in India with much hope and enthusiasm. They believe that IT is not only a key step to improve India in world economic order, but also an vehicle to alter the duress of the abiding cultural order in Indian society. 
In this respect, a closer scrutiny on whether or not the development of IT sector has contributed to improve social mobility of Indians in general is important on three ways. First, it helps us to identify which group are becoming the real beneficiaries of the IT development. Second, it helps us to explain the importance of traditional variables like caste and kinship ties in deciding the degree of opportunities for people of various backgrounds. Third, it helps us to understand the impact that IT and globalization have brought to the life of the Indians. Region-wise, the development of IT and the recipients of IT-related foreign direct investment are concentrated on few states in India, such as Bangalore, Mumbai, Pune, New Delhi, and Chennai (Ernst and Young 2012, 10). These states are located in the western part of India and they make a small section of the large part of Indian states that grows in an unprecedented pace.

In these states, the policy intervention in IT sector initiated by the national government was responded positively by the state government as seen in the pioneering of the engineering colleges and, later, the promotion of their states as IT enclaves. Far behind them are other regions in northern and eastern part of India, such as Bihar, which are deficient of human resources and infrastructure. But, other than policy intervention in both national and regional level, difference in regional history and characteristic also affect human resource preparedness. Cities that had been developed as the center of economic gravitation, such as Mumbai and New Delhi, are relatively easy to adapt to wave of change which is posed by globalization, compared to other cities that are suffered from the lack of resources and infrastructures.

Skill-wise, those people who are benefited from IT industry are those who have already gained minimum requirement of education and language capabilities. In terms of education, a wide gap exists between states, between urban and rural areas, and between religious and cultural division. The gap between states are indicated by the greater variations found in sub-indices of the human development index, namely health and education, in which the state of Kerala stands out among all the other states, especially Orissa, Bihar, and Chattisgarh (Suryanarayana, Agarwal, and Prabu, 2011). Using Kerala as the benchmark, other research conducted by Gopalakrishna and Leelavathi (2011) finds out the HDI index of Kerala is equal to the eight states which have the lowest index. These states include Bihar, Uttar Pradesh, Madhya Pradesh, Rajashtan, and Orissa (Gopalakrishna and Leelavathi 2011, 236).

The gap between states is frequently related to the gap between urban and rural areas. Because some states are more urbanized than other states, access to IT knowledge is more concentrated to the cities, which 
inevitably have better infrastructure and human resources. Without roads, electricity, or basic schools, let alone higher education graduates, it is very unlikely that investors would like to pour their money out and invest in either rural areas or in states with low capacities to increase their human, public, and social sector expenditure while improving their public facilities and developing their human resources (Gopalakrishna and Leelavathi 2011, 240-241).

In addition to it, providing that the gap is prevalent between cultural and religious groups, only those privileged from the system have access to knowledge, skill, and employment related to IT. Irrespective of the dwelling area, unequal distribution of public access to education, health, and employment in India remains due to the widespread discrimination against those standing at the lowest strata of the society. Graph 1 describes, for instance, how Hindu OBC (the Dalits), Muslim, Scheduled Caste (the Sudras), and Scheduled Tribe are all not well represented in the seats of higher education, hence little possibility for them to be equally represented in IT sector, too.

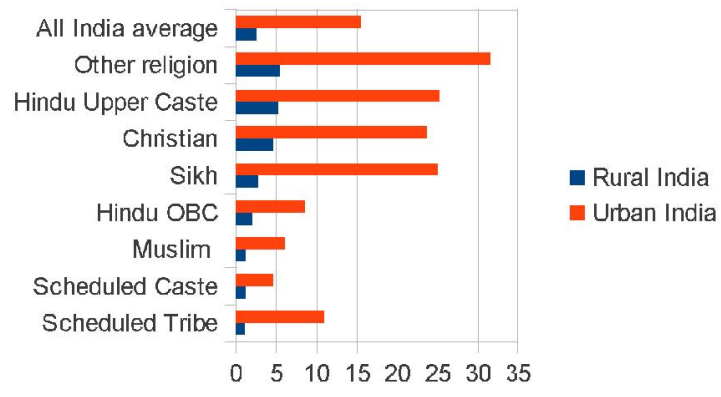

\section{Graph 1. Group Inequalities in Higher Education}

Source: Yadav and Deshpande (2006, online version, no page number can be attributed)

Language-wise, although India is the second largest English user country, the capabilities among the inhabitants are varied from broken English to fluent English. Only those people who are exposed to the use of English language as language of instruction in formal education that are able to master English well, hence adapt to the early opportunities provided by IT sector. Others who are not well exposed to proper education and lack of requisite skills are disbanded by these opportunities. The degree of opportunity and chance are basically related to various factors, which cut across diverse categorical background. Muslims' lowest representation in Indian higher education as seen in Graph 1, for instance, is in fact in corresponds with Muslims' lowest literacy rates as seen in Table 1. But even among Muslims, there 
exists varieties of literacy rate between male and female. Other than that is wide inter-provincial variation in Muslims and non-Muslim literacy rates, in which Muslim literacy rates in Rajashtan, Uttar Pradesh, and Haryana are much lower than the Hindu's but are higher in Andhra Pradesh, Delhi, Karnataka, Madhya Pradesh, Maharashtra, and Orissa.

\begin{tabular}{|c|c|c|c|c|c|c|}
\hline \multirow[t]{2}{*}{ State } & \multicolumn{2}{|c|}{ Muslims } & \multicolumn{2}{|c|}{ Hindus } & \multicolumn{2}{|c|}{$\begin{array}{c}\text { Scheduled Castes/ } \\
\text { Tribes }\end{array}$} \\
\hline & Total & $\mathbf{F} / \mathbf{M}$ & Total & $\mathbf{F} / \mathbf{M}$ & Total & $\mathbf{F} / \mathbf{M}$ \\
\hline All India & 59 & 0.74 & 68 & 0.71 & 56 & 0.67 \\
\hline Rajasthan & 47 & 0.53 & 58 & 0.55 & 42 & 0.44 \\
\hline Bihar & 56 & 0.72 & 58 & 0.58 & 41 & 0.46 \\
\hline $\begin{array}{l}\text { Madhya } \\
\text { Pradesh }\end{array}$ & 73 & 0.70 & 65 & 0.62 & 46 & 0.57 \\
\hline Uttar Pradesh & 51 & 0.66 & 66 & 0.66 & 54 & 0.62 \\
\hline Haryana & 38 & 0.35 & 69 & 0.69 & 56 & 0.67 \\
\hline $\begin{array}{l}\text { Himachal } \\
\text { Pradesh }\end{array}$ & 67 & 0.61 & 82 & 0.82 & 74 & 0.75 \\
\hline Punjab & 48 & 0.61 & 74 & 0.83 & 62 & 0.74 \\
\hline West Bengal & 56 & 0.77 & 81 & 0.86 & 61 & 0.79 \\
\hline Gujarat & 61 & 0.54 & 71 & 0.70 & 61 & 0.67 \\
\hline Maharashtra & 79 & 0.79 & 77 & 0.77 & 66 & 0.70 \\
\hline Andhra Pradesh & 59 & 0.68 & 55 & 0.69 & 47 & 0.66 \\
\hline Karnataka & 74 & 0.79 & 69 & 0.72 & 55 & 0.65 \\
\hline Kerala & 92 & 0.93 & 94 & 0.94 & 86 & 0.99 \\
\hline Tamil Nadu & 63 & 1.3 & 71 & 0.81 & 58 & 0.70 \\
\hline Orissa & 90 & 0.87 & 72 & 0.75 & 57 & 0.63 \\
\hline $\begin{array}{l}\text { Jammu \& } \\
\text { Kashmir }\end{array}$ & 53 & 0.67 & 77 & 0.82 & 73 & 0.74 \\
\hline Jharkhand & 53 & 0.64 & 67 & 0.67 & 50 & 0.60 \\
\hline Chhattisgarh & 48 & 0.41 & 62 & 0.65 & 46 & 0.56 \\
\hline Uttarakhand & 58 & 0.65 & 82 & 0.77 & 66 & 0.74 \\
\hline Assam & 67 & 0.89 & 85 & 0.96 & 81 & 0.87 \\
\hline Delhi & 88 & 0.92 & 85 & 0.82 & 86 & 0.84 \\
\hline
\end{tabular}

Notes: figures have been rounded; $\mathrm{F} / \mathrm{M}=$ female-to-male ratio

Table 1. Minority-majority literacy rates in rural India by state, ethnicity, and gender (7 years and above), 2004-05 (\%)

Source: Bhalla and Luo (2013), p. 125

Employment-wise, Indians are absorbed mostly in agricultural and unorganized sector. Based on Graph 2, it is revealed that share of employment in private sector is the smallest within which IT industry are a part of. Being concentrated only to small percentage of active workers, the high income enjoyed by people employed in this sector becomes a privilege that favors few people against unequal others. 


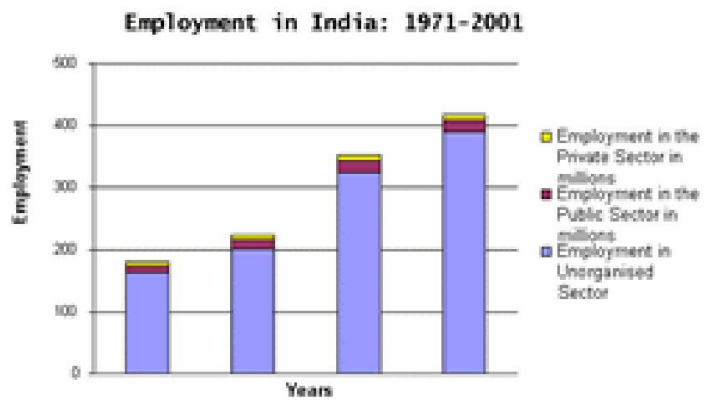

Graph 2. Share of employment in India (1971-2001)

Source: Sinha (no date), 15

Radhakrishnan (2011) in her book argued that IT sector represents the new India, in which merit becomes the basis for professional Indians (see Table 2). In her book, she compares to two types of employments, namely merit-based and reserved-based employment, in which IT belongs to the earlier. She argues that only by forwarding the idea of merit-based employment the Indians can get over with their strictly cultural-based division on the one hand and, as one of the result, economic backwardness on the other hand. Her evaluation is based on the general assumption that the governmental jobs are prone to corruption since those posts are held by incapable people yet posses the rights to work. Her assumption is in respond to the reservation policy which gives preference over people who are less privilege, such as the Hindu OBC, Muslim, Scheduled Caste, and Scheduled Tribes, to get access to education and employment, including posts in governmental office. Instead of educating the people to be competitive, reservation policy has given a leeway for the beneficiaries to rely on their cultural ties, hence strengthening the cultural division which is already profound in society. IT is then projected to diminish inequalities and provide equal opportunities for all.

\begin{tabular}{ll}
\hline \multicolumn{1}{c}{ Merit } & \multicolumn{1}{c}{ Reservation } \\
\hline Private sector job & Government job \\
Economy/free market & State \\
Professionalism & Politics/corruption \\
Global & Parochial \\
Efficiency & Bureaucracy \\
Virtue/hard work & Laziness/stagnation \\
\hline Individual growth & Supression of individual \\
Flat management & Hierarchy \\
\hline
\end{tabular}

Table 2. IT Sector: Equality for all? Source: Radhakrishnan (2011) 
While it is true that those people under the ladder of the society are likely to be incompetent due to the lack of knowledge and skills, it lacks from comprehension that the widespread structural discrimination and/or inequalities persist in various axes of categories. As already been discussed earlier, IT sector is not a neutral site but a site of contestation instead, which arises out of axes inequalities and favors those already enjoying the privilege. Although government has intervened to increase the number of participation to, and improve the qualities of, education among marginal groups through reservation policy, the policy itself fails to lift the prejudice that hang over the society.

A research by Thorat, Attewell, and Rizvi (2009) show how discrimination remains important in private-sector labor market in urban India. Using fictitious names of upper-caste Hindu, Dalits, and Muslims, the researchers conduct a correspondence study of job applicants by responding to newspaper job advertisement. The research finds that the company shows poorer responses to Dalit and Muslim applicants despite their having almost identical qualification and experience with their upper-caste Hindu counterpart. The research concludes, "caste favoritism and social exclusion of Dalits and Muslims occur in private enterprises even in the most dynamic modern sector of the Indian economy" (Thorat et al. 2009, 14). As a matter of fact, discrimination is likely to be much higher in the private than in the public sector. This is because all public sectors in India are nowadays subject to the implementation of reservation policy, in which the employment of marginal groups in government office will enable them to uplift their economic backwardness and guarantee their children for higher social mobility.

Policy intervention indeed has something to say in altering the fate of the minorities, to refer to not only marginalization on caste or religious based group, but also on gender category. A research conducted by Arun, Heeks, and Morgan (2004) from the Institute of Development Policy and Management, Manchester University, shows how two state-led program regarding IT development in Kerala, named TechnoPark and Kudumbashree, have brought about different impact for women. TechnoPark was developed by sheer interest of making out of economic globalization and competition, while Kudumbashree was set up as one of the various, yet integrated, approach to fight poverty which is genderblind and participatory oriented. The result shows that the marketoriented approach of TechnoPark initiative could only bring about a short-term benefit for women in relations to employment and income. As for the gender-blind Kudumbashree program, it creates more sustainable impacts because, unlike TechnoPark where women occupy position below the managerial level, Kudumbashree prioritizes women 
to run strategic position hence enables them to exercise their decision making capabilities and to organize a small business-like organization. Thus, other than mere economic employment and income, Kudumbashree empowers women through organizational and leadership capacities.

It is evident that in the success story of Kudumbashree, a significant degree of institutional supports from, at least, the state governmental departments and civil society are required. Compared to Indian women in general, women in Kerala are better off in terms of level of education as it shows in Kerala's astounding accomplishment in all HDI components. Based on HDI, women in Kerala have the highest literacy rates and life expectancy rates. Without government intervention, there may not be promotion for women's advancement through access to basic education, let alone higher education, which came first as the building block for their enablement in ITC employment. Other than policy intervention, location specific history and culture also have their parts in providing a sound base for women's advancement in public life. Culture in Kerala is relatively matriarchal and women's participation in various public activities is quite common. This characteristic may not easily be found elsewhere in India.

Gender-wise, the state of women in India presents wide disparities in relations to access to education, health care facilities, and economic employment. In rural India, there is a strong value attached to son and this brings to family's higher investmentin nurturing male than female children (Barcellos et al. 2013). In practice, strong son preference can be seen in persistently accepted practices that giver privilege to son over daughter, including sex-selective female abortion, female infanticide, and the deliberate neglect of female children. This phenomenon, famously known as "the missing girl" (Sen 1990, 61), may only partly explain cases that happen in Indian rural areas and, to some extent, among families in urban areas, especially those with low economic income, lower caste, and other marginal population group, but not among the urban middle class Indians. In the latter group, gender transformation is in fact being underway and, given their educational level and better conception of child nurturance, they do not have strong value attached to son as the former groups' as indicated to the equal importance they give to girls' higher education as to that of boys'. As a consequence, their children are relatively adaptive and able to take advantage of India's unprecedented onrush of globalization. A research conducted by Clark and Sekhar (2007) on women employed in IT sector in Bangalore suggests that there are more and more urban female middle class Indians absorbed in economic sector which required higher advantage of the new world market and job opportunities that are emerging. Highly educated and English speaking, these women even see 
that working in high-tech sector not only an opportunity to improve their economic wellbeing and greater mobility, but also a chance to improve their social standing and acceptance in India's male-dominate society. Overtly exposed to rationalist idea of equal double-income family, these women are more career-oriented, they tend to have planning to become financially dependent.

\section{Conclusion}

Based on the aforementioned discussion, human resources and language play important role in disseminating the opportunities born by IT industries. But, diversities are still to be found as axes of inequalities a flourished among states, due to regional state intervention, rural and urban proximities to educational institution, language exposure, level of education, and group capabilities. The discussion also reveals that a large section of the society is not receiving any benefit provided by available job market generated by Indian global interconnection to the world due to cultural impediment, which strengthens the layers of discrimination and creates basis for and axes of inequalities. Hence, despite the pace of development of Indian IT industry, the benefit does not really trickle down to the largest part of the population, but double back to those already being privileged by the existing societal system instead. In spite of this glooming feature, urban female middle class is the most notable exception.

The discussion explicates that urban female middle class holds basic requirement to entering and competing in IT sector, namely skill competence and English aptitude. Without these two elements of qualifications, the fruits of IT sector will remain in the hands of the few sections in the society that already keep pace with the globalization. In this respect, the key step to accelerate the IT development is to ensure the facilitation of public infrastructure and human resource development through education and health systems. In view of these requirements, a significant degree of institutional support in improving the representation and access of the minorities in educational institution is inevitable so much so that they are able to track down the same opportunities of job employment and social mobility which are already brought by India's embracement to globalization.

\section{Acknowledgment}

The field observation was conducted from August 2009 until June 2010, while the writer was IRTP scholar at Center for Studies in Social Sciences Calcutta (CSSSC). Financial support from SEPHIS (The South- 
South Exchange Program for the History of Development), Amsterdam, for the completion of IRTP (International Research Training Program) in India is gratefully acknowledged. Availing from field observation while staying in India, the analysis in this paper came out of first hand impression as well as supporting evidence from rudimentary data on relevant subjects. All errors remain on the writer's.

\section{Reference List}

\section{Books}

Bell, Daniel, 1973. The Coming of Post-Industrial Society: A Venture in Social Forecasting. New York: Basic Book.

Bhalla, A.S. and Dan Luo, 2013. Poverty and Exclusion of Minorities in China and India. Basingstoke, Hampshire: Palgrave Macmillan.

Das, Gurcharan, 2010. India Unbound. New Delhi: Viking.

Lapierre, Dominique, 1985. City of Joy. New York: Warner Book, Inc.

Radhakrishnan, Smitha, 2011. Appropriately Indian: Gender and Culture in a New Transnational Class. Durham and London: Duke University Press.

\section{Journal Articles}

Clark, Alice W. and T.V. Sekher, 2007. "Can career-minded young women reverse career minded discrimination? a view from Bangalore's high-tech sector", Gender Technology and Development, 11 (3): 285-319

Gopalakrishna, B.V. and D.S. Leelavathi, 2011. "Infrastructure and human development in India: an inter-state comparison", Journal of Global Economy, October-December 2011, 7 (4): 225-244.

Kellner, Douglas, 2002. "Theorizing Globalization", Journal of Sociological Theory, 20 (3): 285-305.

\section{Working Paper Articles}

Arun, Shoba, et al., 2004. "ICT initiatives, women works, and developing countries: reinforcing or changing gender inequalities in South India?" Manchester University Institute for Development Policy and Management, Development Informatics Working Paper Series, Paper No. 20 [online] in http://espace.openrepository.com/e-space/bitstream/2173/97901/ 1/di_wp20.pdf [accessed February 24th, 2014]

Thorat, Sukhadeo, et al., 2009. "Urban Labor Market Discrimination", Indian Institute of Dalit Studies Working Paper Series, 3 (1) 
[online] in http://www.dalitstudies.org.in/download/wp/o901.pdf [accessed February 27th 2014]

\section{Reports}

Ernst and Young, 2012. India: Ready for the Transitions. Ernst and Young's 2012 Attractiveness Survey [online] in http://emergingmarkets.ey.com/.../2012/.../india-attractivenessfinal-version... [accessed January 26th 2013]

Suryanarayana, M.H, Agarwal, Ankush, and Prabhu, K. Seeta, 2011. Inequality-adjusted Human Development Index for India's States. UNDP-India.

\section{Articles in Magazines and Newspaper}

Business Standards, 2008. "India has fewer poor people: World Bank", Business Standards, August $27^{\text {th }} 2008$ [online] in http://www.business-standard.com/india/ storypage.php?autono $=332669$ [accessed January $27^{\text {th }}$ 2013]

IBNLive, 2008. "Number of poor people in India has gone up: World Bank", IBNLive, August $26^{\text {th }} 2008$ [online] in http://ibnlive.in.com/news/number-of-poor-in-India-has-gone-upworld-bank/72227-3.html [accessed January 27th 2013]

Sen, Amartya, 1990. "More than 100 million women are missing", New York Review of Books, December 20 ${ }^{\text {th }}$ 1990: 61-66.

Yadav, Yogendra and Satish Deshpande, 2006. "Mandal II: an alternative proposal", Outlook India, May $24^{\text {th }} 2006$

\section{Online Articles}

Arora, Ashish and Surendrakumar Badge, 2007. "The Indian software industry: the human capital story" [online] in http://www2.druid.dk/conferences/viewpaper.php?id=789\&cf $=8$ [accessed January $2^{\text {nd }}$ 2013]

Dossani, Rafiq, 2005. "Origins and growth of software industry in India" [online] in http://www.iis-db.standford.edu/pubs/20973/...,2005sbs.ox.ac.uk [accessed January $27^{\text {th }}$ 2013]

Sinha, Aseema, no date. "Globalization, rising inequality, and new insecurities in India" [online] in http://www.apsanet/org/imgtest/ taskforcediffineqdevsinha.pdf/ [accessed January 22 $2^{\text {nd }}$ 2013]

Barcellos, Silvia Helena, et al., 2013. "Child gender and parental investment in India: are boys and girls treated differently?" [online] in http://works.bepress.com/cgi/viewcontent.cgi?article= $1001 \&$ context=silvia_barcellos [accessed February $26^{\text {th }} 2014$ ]. 